\title{
POTENSI AKTIVITAS ANTIMIKROBA MADU DAN HABBATUSSAUDA TERHADAP BAKTERI ESCHERICHIA COLI SECARA IN VITRO
}

\author{
Alifia Ayu Delima ${ }^{1}$,Utami Murti Pratiwi ${ }^{2}$, Asriani $^{3}$, \\ Sri Rezki Wahdania Jamaluddin ${ }^{4}$ Indra Sari ${ }^{5}$ \\ ${ }^{1,2}$ Departemen Biomedik, Fakultas Kedokteran dan Ilmu Kesehatan, UIN Alauddin Makassar \\ ${ }^{3}$ Departemen Ilmu Peyakit Dalam, Fakultas Kedokteran dan Ilmu Kesehatan, UIN Alauddin Makassar \\ 4,5 Program Studi Pendidikan Dokter, Fakultas Kedokteran dan Ilmu Kesehatan, UIN Alauddin Makassar \\ e-mail : alifiaayudelima@gmail.com
}

\begin{abstract}
Abstrak
Madu dan habbatussauda memiliki aktivitas antibakteri. Komponen yang terdapat di dalam madu antara lain keasaman, tekanan osmotik, dan hidrogen peroksida, asam aromatik serta omponen fenol juga berperan dalam aktivitas antibakteri. Sedangkan habbatussauda sendiri tannin, tymoquinon, thymol, a-pinene, p-cymene dengan cara menghambat pembentukan asam nukleat (RNA) dan sintesis protein yang berperan sebagai antibakteri dan antioksidan pada proses infeksi. Tujuan dari penelitian ini untuk mengetahui potensi antibakteri madu dan Habbatussauda terhadap bakteri Escherichia coli. Jenis penelitian ini adalah eksperimental dengan metode Post Test Only Control Group Design yang dilakukan secara in vitro. Hasil dari penelitian in vitro menunjukan bahwa terdapat pengaruh pemberian perlakuan madu, habbatussaudah dan kombinasi terhadap daya hambat pertumbuhan e-coli $(<0.05)$.
\end{abstract}

Kata kunci : madu, habbatussauda, escherichia coli, antibakteri

\begin{abstract}
Honey and Black Seed have antibacterial activity. The components contained in honey include acidity, osmotic pressure, and hydrogen peroxide, aromatic acids and phenol components also play a role in antibacterial activity. Meanwhile, Black Seedtannins, containstymoquinone, thymol, apinene, and p-cymene by inhibiting the formation of nucleic acid (RNA) and protein synthesis that act as antibacterial and antioxidant in the infection process. The purpose of this study was to determine the antibacterial potential of honey and Black Seed against Escherichia coli bacteria. This type of research is experimental withmethod Post Test Only Control Group Design which is carried out in vitro. The results of the in vitro study showed that there was an effect of the treatment of honey, Black Seed and the combination on the inhibition of the growth of e-coli $(<0.05)$.
\end{abstract}

Keywords : honey, black seed, escherichia coli, antibacterial

\section{PENDAHULUAN}

Penyakit infeksi saluran pencernaan dapat disebabkan oleh virus, bakteri dan protozoa. Infeksi yang disebabkan oleh bakteri dikenal sebagai disentri basiler yang disebabkan oleh bakteri shigella, sedangkan infeksi yang disebabkan oleh protozoa dikenal sebagai disentri amuba (Anorital, 2011). Salah satu penyakit infeksi saluran pencernaa yang sering terjadi adalah diare. Diare sendiri merupakan suatu penyakit gangguan pencernaan yang masih menjadi masalah kesehatan di negara berkembang, 
karena masih sering timbul dalam bentuk kejadian luar biasa (KLB) dan menjadi penyebab kematian utama bayi dan balita khususnya di Indonesia (Christy,2014;Angraeni,2011; Cholid,2010; Widoyono,2011).

Menurut World Gastroenterology Organisation Global guidlines 2005, terdapat empat penyebab terjadinya diare akut yaitu bakteri virus, parasit dan non infeksi. Dimana berdasarkan penelitian Hermawanto, penyebab diare dengan prevalensi terbanyak disebabkan oleh E.coli dengan frekuensi 38,29\% kemudian disusul oleh Vibriocholerae, Aeromonas sp, dan Shigella flexneri. Enteropathogenic E. coli (EPEC) merupakan salah satu galur dari $E$. Coli yang menyebabkan terjadinya diare berdarah atau berair (WGO,2005). Dimana, EPEC melakukan infeksi dengan cara melekat pada permukaan mukosa usus dan kemudian merubah permukaan struktue epitel usus. Setelah itu, akan melakukan invasi masuk ke dalam sel mukosa usus dan membentuk koloni di usus sehingga menyebabkan terjadinya infeksi dan diare (Arief, 2010 dan Astawan, 2011). Data KEMENKES tahun 2011 menyebutkan diare membunuh 100.000 balita Indonesia setiap tahunnya (KEMENKES, 2011). Survei Morbiditas oleh Kementerian Kesehatan pada tahun 2010 menunjukkan bahwa proporsi terbesar $(21,65 \%)$ penderita diare pada balita adalah kelompok umur 611 bulan. Disusul kelompok umur 12-17 bulan sebesar 14,43\%, kelompok umur 2429 bulan sebesar $12,37 \%$, dan yang terkecil pada rentang umur 54-59 bulan yaitu 2,06\% (Angraeni, 2011 dan Biswas, 2013). Melihat angka kejadian diatas, maka diperlukan suatu pengobatan untuk mengurangi angka kejadian tersebut. Salah satu pengobatan yang sering dilakukan adalah pengobatan konvensional.

Pengobatan konvensional yang banyak dilakukan untuk diare adalah dengan pemberian antibiotik oral (Mubasyiroh, 2010). Menurut Centers For Disease Control and Prevention, setiap tahun di Amerika Serikat terdapat dua juta orang yang terinfeksi oleh bakteri yang telah resisten terhadap antibiotik dan setidaknya 23.000 orang meninggal setiap tahun akibat resistensi ini. Hal ini terjadi karena buruknya regulasi, kurangnya pengawasan penggunaan antibiotik serta kebiasan masyarakat untuk mencari jalan pintas dalam mengobati penyakit. Pemberian antibiotik ini memungkinkan bakteri akan berdaptasi dalam melawan antibiotik dengan cara membentuk strain-strain baru sehingga menimbulkan resistensi terhadap antibiotik (Mubasyiroh, 2010 dan Komala, 2008). Kondisi inilah yang membuat penelitian 
mulai diarahkan untuk mencari pengobatan alternatif yang efektif dalam mengobati diare. Berdasarkan penelitian, Madu dan Habbbatussada (MAHA) dapat digunakan dalam mengobati diare tanpa menimbulkan resistensi.

Pengobatan dengan madu dan habbatussauda juga telah disebutkan dalam Al-Quran dalam surat An-Nahl: 69 yang mengatakan bahwa madu yang keluar dari perut lebah dapat dijadikan sebagai prebiotik, pengganti gula dalam oralit serta sebagai antimikroba (Herawati, 2017). Selain itu dijelaskan dalam hadis Rasulullah SAW yang berbuyi: "Tetaplah kamu berobat dengan habbatussauda, karena sesungguhnya ia mengandung bahan penyembuh bagi setiap penyakit kecuali mati" (Hadist Al Bukhori) (Jaksa, 2010).

Kandungan antibakteri di dalam madu seperti hidrogen peroksida, polyphenol, glikosida, dan flavonoid. Selain itu, ditambah dengan kemampuan antibakteri dari habbatussauda itu sendiri yaitu mengandung thymoquinone, tanin dan thymohydroquinone (Asniyah, 2009). Thympquinonedan thymohydroquinone diduga dapat membentuk kompleks yang irreversible dengan asam amino nukleofilik pada protein bakteri sehingga menyebabkan inaktivasi protein. Sementara tanin bekerja dengan mengadakan komplek hidrofobik dengan protein, menginaktivasi adhesi, enzim dan protein transport dinding sel, sehingga mengganggu pertumbuhan bakteri. Selain itu, kandungan Senyawa aktif yang terkandung didalam biji $N$ sativa diantaranya adalah Nigellisine, nigellidine, nigellimine-N-oksida, thymoquinone, dithymoquinone, thymohydroquinon, nigellone, thymol, arvacrol, oxycoumarin, 6methoxycoumarin, dan 7- hydroxycoumarin, alpha-hedrin, sterylglucoside, selain itu juga mengandung flavinoids, tannins, asam amino esensial, asam askorbat, besi dan kalsium (Mashadian, 2005).

\section{METODE}

Penelitian Post Test Only Control Group Design secara in vitro ini dilakukan di Laboratorium mikrobiologi Balai Besar Laboratorium Kesehatan Kota Makassar dan Laboratorium Penelitian Prodi Pendidikan Dokter UIN Alauddin Makassar pada bulan Juni- juli 2019.

\section{Uji InVitro}

Madu yang digunakan adalah madu jenis Randu yang diberikan dengan konsistensi cairan menggunakan dosis 20mg/kgBB diberikan 2 jam sebelum mencit makan atau 3 jam setelah mencit (inbreed mice) makan. Untuk habattusauda diberikan 
berupa kapsul dengan dosis $80 \mathrm{mg} / \mathrm{kgBB}$ secara oral. Keduanya diberikan setiap hari. Mencit yang digunakan sebanyak 24 ekor yang telah dipaparkan oleh bakteri E.coli dan dibagi ke dalam 4 perlakuan:

- Kelompok 1 : pemberian aquades (kontrol)

- Kelompok 2 : pemberian madu

- Kelompok 3 : pemberian habbatussaudah

- Kelompok 4 : pemberian kombinasi kombinasi Madu dan Habbatusauda.

\section{Analisis Data}

Analisis data menggunakan aplikasi SPSS dengan analisis One Way Anova.

\section{HASIL}

Penelitian ini dilakukan dengan melihat kemampuan dari antibakteri madu dan habbatussauda terhadap pertumbuhan E.coli secara in vitro dengan menggunakan konsentrasi 25\%, 50\%, 75\%, 100\% dengan 2 kali pengulangan. Adapun hasil penelitian dapat dilihat pada tabel 1 .

Tabel 1 menunjukan hasil analisis varians. Perlakuan berupa madu, habbattusaudah dan kombinasi keduanya berpengaruh nyata terhadap e-coli. Konsentrasi berupa 25\%, 50\%, 75\%, 100\%, positif dan negatif tidak berpengaruh secara nyata terhadap e-coli. Sedangkan kombinasi antara perlakuan dengan konsentrasi menunjukan terdapat pengaruh yang nyata.

\section{PEMBAHASAN}

Hasil penelitian secara in vitro menunjukkan bahwa madu dan habbatussauda memiliki efek antimikroba terhadap pertumbuhan e.coli. Hal ini telah sesuai dengan hipotesis sebelumnya yang menunjukkan bahwa madu dan habbatussauda memiliki aktivitas dalam menghambat pertumbuhan bakteri. Madu memiliki aktivitas antibakteri, anatara lain keasaman, tekanan osmotik, dan hidrogen peroksida. Komponen tambahan pada madu seperti asam aromatik serta omponen fenol juga berperan dalam aktivitas aantibakteri. Komponen seperti lisozim, asam fenolik dan flavonoid juga terdapat daalam madu.

Komponen fenolik lainnya pada nektar juga memiliki aktivitas antioksidan. Keasaman memiliki pengaruh yang besar terhadap pertumbuhan dan kelangsungan hidup bagi sel bakteri. Ketika $\mathrm{pH}$ turun sampai batas terendah untuk pertumbuhan bakteri, tidak hanya sel bakteri yang akan berhenti pertumbuhannya, tetapi bakteri juga akan kehilangan kemampuan hidupnya. Keasaman yang tinggi dapat berpengaruh pada komponen sel dan memberikan pengaruh yang merugikan terhadap struktur sel. Faktor kedua yang menyebabkan madu 
memiliki aktivitas antibakteri adalah efek osmotik. Interaksi yang kuat antara molekul gula dengan molekul air menyebabkan molekul air yang sangat sedikit tersedia bagi bakteri sedangkan air bebas dibutuhkan untuk pertumbuhan bakteri (Molan 1992 dalam Jeffrey 1997). Air bebas dibutuhkan untuk transpor nutrien dan membuang sisa metabolit, mengeluarkan reaksi enzimatis, mensintesis bahan-bahan sel, dan melakukan reaksi biokimia yang lain (Ray, 1996).

Madu juga diindikasikan terdapat senyawa fenol yang bersifat antibakteri (Jeffrey, 1996). Beberapa senyawa fenol tersebut adalah pinocembrin, terpenes, benzyl alcohol, syringic acid, methyl syringate, 1,4-dihydroxybenzene dan flavonoid. Mekanisme senyawa fenol sebagai zat antibakteri adalah dengan cara meracuni protoplasma, merusak dan menembus dinding sel, serta mengendapkan protein sel mikroba. Komponen fenol juga dapat mendenaturasi enzim yang bertanggung jawab terhadap germinasi spora atau berpengaruh terhadap asam amino yang terlibat dalam proses germinasi. Terjadinya kerusakan pada membran sel mengakibatkan terhambatnya aktivitas dan biosintesis enzim-enzim spesifik yang diperlukan dalam reaksi metabolisme (Yulianti, 2009).

Habbatussauda sendiri sebagai antibakteri dan juga antioksidan yang berperan pada proses infeksi. Golongan hidrokarbon terkosigenasi (fenol) memiliki daya antibakteri yang sangat kuat. Pada tahun 1992, Jurnal Farmasi Pakistan memuat hasil penelitian yang membuktikan volatil lebih ampuh untuk membunuh strain bakteri V Cholera dan E. Coli dibandingkan dengan antibiotik seperti ampicillin dan tetrasiklin (Junaedi, 2011 dan Gilani, 2004).

Aktivitas antimikroba habbatussauda disebabkan oleh komponen utamanya yaitu tannin, tymoquinon, thymol, a-pinene, $p$ cymene dengan cara menghambat pembentukan asam nukleat (RNA) dan sintesis protein. Tymoquinon sebagai komponen utama dapat menyebabkan tidak aktifnya protein bakteri sehingga protein kehilangan fungsinya serta meniadakan substrat bagi mikroorganisme. Thymoquinone berfungsi sebagai antiinflamasi dengan cara menghambat jalur siklo-oksigenase dan lipooksigenase yang berfungsi sebagai mediator alergi dan peradangan. Pada sebuah penelitian, ditemukan bahwa habbatussauda mempu meningkatkan fungsi sel polymorphonuclear (PMN) dan mampu menstimulasi sitokin Macrophage Activating Factor (MAF) sehingga meningkatkan fungsi makrofag yang berperan dalam sistem imun seluler. Thymoquinone yang memiliki efek antiinflamasi, dengan mekanisme antara lain 
menurunkan sitokin Th2 yaitu IL-4, IL-5 dan IL-13; lung eosinophilia, lipoksigenase serta siklooksigenase, serum $\operatorname{IgE}$, menghambat influks $\mathrm{Ca} 2+$ sehingga dapat mencegah degranulasi sel mast serta menurunkan TNF (Husna, 2008; Nergiz, 1993; El-Dakhakhny, 2002; Chakravarty, 1993 dan Todar, 2008).

Thymol merupakan turunan dari fenol. Aksi fenol melawan dinding sel bakteri relatif kompleks dan mungkin diantaranya termasuk denaturasi protein dengan kerusakan membran sel yang menyebabkan kebocoran komponen intraseluler. (Raisa, 2009 dan Erlyn, 2012). Tannin yang terdapat dalam habbatussauda mampu membentuk ikatan komplek dengan protein sehingga dapat menginaktivasi adhesion bakteri, enzim, dan lain-lain. Selain itu menurut penelitian yang lain tannin berperan dalam aksi molekulernya yang berikatan dengan protein melalui tekanan pada ikatan hydrogen dan efek hidrofobik, yang mana sesuai dengan formasi ikatan kovalen.

Tannin juga merupakan senyawa fenol yang bekerja dengan cara menghambat pertumbuhan bakteri dengan mengadakan denaturasi protein dan menurunkan tegangan permukaan sehingga permeabilitas bakteri meningkat. Kerusakaan dan peningkatan permiabilitas sel bakteri menyebabkan pertumbuhan sel terhambat dan akhirnya dapat menyebabkan kematian sel. Tannin juga mempunyai gugus galoil dan gugus pirogalol yang mempunyai sifat antibakteri. Kedua gugus tersebut bereaksi dengan protein membran bakteri yang mengakibatkan rusaknya membran sitoplasma bakteri, sehingga fungsi membran sebagai barier permeabilitas selektif, transpor aktif, dan mengatur komposisi internal sel tersebut rusak, makromolekul dan ion keluar dari sel, kemudian sel rusak dan mengalami kematian (Rahmanita, 2014 dan Yusuf, 2014).

\section{KESIMPULAN}

Berdasarkan hasil penelitian, diketahui bahwa madu dan habbatussauda memiliki efek dalam menghambat pertumbuhan bakteri E.coli secara in vitro.

\section{DAFTAR PUSTAKA}

1. Anorital, Lelly Andayasari. 2011. Kajian Epidemiologi Penyakit Infeksi Saluran Pencernaan Yang Disebabkan Oleh Amuba Di Indonesia. Epidemiological Study of Intensial Infection Caused By Amoeba In Indonesia. Litbang Kesehatan. Vol. 2 No 1.

2. Biswas B, Rogers K, McLaughlin F, Daniels D, Yadav A. Antimicrobial activities of leaf extracts of guava (Psidium guajava L. L.) on two gram-negative and gram-positive bacteria. International Jurnal of Microbiology. 2013.

3. Buckle, K.A., R.A. Edwards, G.H. Fleet, dan M. Wootton, . Ilmu Pangan (Terjemahan Hari Purnomo dan Adiono). 
Jakarta : Direktorat Jenderal Pendidikan Tinggi. 1985: Hal : 23, 29.

4. Chakravarty N. Inhibition of histamine release from mast cells by Nigellone. Ann Alergy 1993; 70: 237-242.

5. Cholid S." Pengaruh Pemberian Madu Pada Anak Yang Menderita Diare Akut Cair Dengan Dehidrasi Ringan Sedang "[Tesis]. Program Pascasarjana Magister Ilmu Biomedik dan Program Pendidikan Dokter Spesialis Ilmu Kesehatan Anak Universitas Dipenegoro Semarang. Hal: 830.2010 .

6. Al-Mubarakfuri, Syaikh Shafiyyurrahman. Shahih Tafsir Ibnu Katsir. Jakarta:Pustaka Ibnu Katsir, 2018.

7. Alvarez-Uria,et al. Global forecast of antimicrobial resistance in invasive isolates of Escherichia coli and Klebsiella pneumoniae. International Journal of Infectious Diseases, 68,2018: 50-53.

8. Anggraeni, N.D., dan Farida. S., 2011. Situasi Diare di Indonesia. Buletin Jendela Data dan Informasi Kesehatan, Triwulan II: $1-6$.

9. Anggraeni, N.D., dan Farida. S., 2011. Situasi Diare di Indonesia. Buletin Jendela Data dan Informasi Kesehatan, Triwulan II: $1-6$.

10. Asniyah.Efek anti mikroba minyak jintan hitam(nigella sativa) terhadap pertumbuhan E.coli in vitro. Jurnal biomedika. 2009.(1):[26-9].

11. Astawan. M., T. Wresdiyati, I. I. Arief, dan E. Suhesti. Gambaran Hematologi Tikus Putih (Rattus norvegicus) yang Diinfeksi Escherichia coli Enteropatogenik dan Diberikan Probiotik. Media Peternakan. $2011: 7-13$.

12. Arief, I.I., B. Sri L. J., M. Astawan dan A. B. Witarto. Efektivitas Probiotik Lactobacillus plantarum 2C12 dan Lactobacillus acidophilus 2B4 Sebagai Pencegah Diare pada Tikus Percobaan. Media Peternakan. 2010. 33 (3).

13. Christy, Meivi Yusinta. 2014. Faktor Yang Berhubungan Dengan Kejadian Dehidrasi Diare Pada Balita Di Wilayah Kerja Puskesmas Kalijudan.

14. El-Dakhakhny M, Madi NJ, Lambert N, Ammon HP. Nigella sativa oil, nigellone and derived thymoquinone inhibit synthesis of 5-lipoxygenase products in polymorphonuclear leukocytes from rats. J Ethnopharmacol 2002; 81:161-164.

15. Erlyn aprilia dkk. 2012. Efektifitas ekstrak nigella sativa untuk mengurangi bakteri plak subgingiva. Surabaya. FKG Unair.

16. Erlyn aprilia dkk. 2012. Efektifitas ekstrak nigella sativa untuk mengurangi bakteri plak subgingiva. Surabaya. FKG Unair.

17. Gilani AH, Jabeen Q, Khan MAU. A review of medicinal uses and pharmacological activities of Nigella sativa. Pak J Biol Sci 2004; 4:441-451.

18. Hadits Al-Bukhari no. 5688/Al-Fath X/143, dan Muslim no. 2215 dari Abu Hurairah Radhiyallahu =anhu. Lafazh ini adalah lafazh Muslim.

19. Herawati, Rika. 2017. Pengaruh Pemberian Madu Terhadap Penurunan Frekuensi Diare pada Anak Balita di RSUD Rokan Hulu. Riau: UPP.

20. Husna, Mujaidah. 2008. Pengaruh pemberian jinten hitam terhadap kadar glukosa pada tikusdiabetes akibat induksi aloksan. Surakarta: Universitas Sebelas Maret.

21. Jaksa, Suherman. 2010. Minyak Atsiri Dari beberapa tanaman obat. Jurnal kedokteran dan ilmu kesehatan. Vol.6 No. 1. Jakarta: Universitas Muhammadiyah Jakarta.

22. Jeffry AE, Echazaretta CM.Medical Uses Of Honey.Rev Biomed.1996:43-49

23. Junaedi, dkk.2011. Kedahsyatan Habbatussauda mengobati beberapa penyakit. Jakarta: PT. AgroMedia Pustaka

24. Kemenkes. R.I., 2011. Panduan Sosialisasi Tatalaksana Diare pada Balita. Jakarta; Ditjen PP \& PL: 9.

25. Kementerian kesehatan RI. Buku Saku Petugas Lintas Diare. Jakarta: Dirjen Pengendalian Penyakit dan Peyehatan Lingkungan Kementrian Kesehatan RI.2011.

26. Komala O, Ismanto. Daya antimikroba ektrak tanaman obat terhadap bakteri Staphylococcus aureus. Ekologia. 2008;8(2):29-36.

27. Mashhadian, N.V., Rakhshandeh, H. 2005. Antibacterial and antifungal effects of $N$. Sativa extracts against $S$. aureus, $P$. aureginosa, and C. albicans., Pak. J. Med. Sci., 
28. Molan P.C. 1992. The Antibacterial activity of honey. Bee World; 73:5-28.

29. Mubasyiroh, Rofingatul. 2010. Faktor Yang Berhubungan Dengan Kejadian Diare Pada Balita Di Beberapa Iwgional Indonesia Tahun 2007. DEPKES: Puslitbang Ekologi dan Status Kesehatan Litbang Depkes.

30. Nergiz C, Ötles S. Chemical composition of Nigella Sativa L. seeds. Food Chem 1993; 48:259-261.

31. Ray, B.. Fundamental Food Microbiologi. CRC Press: New York. Page 1996: 410411, 402-403.

32. Rahmanita, Hania Asmarani. 2014. Efek Ekstrak Biji Jinten Hitam (Nigella sativa) Terhadap Jumlah Spermatozoa Mencit yang Diinduksi Gentamisin. Jakarta: UIN Syarif Hidayatullah.

33. Raisa adhiba dkk. 2009. Obat kumur jintan hitam (nigella sativa) $17,5 \%$ terhadap penurunan gingivitis. Surabaya. FKG Unair.
34. Todar. 2008. Jinten hitam (N. sativa) sebagai antibakteri terhadap pertumnuhan pseudomonas aeruginosa dan staphylococcus aureus. Jakarta: UPI.

35. World Gastroenterology Organisation. Global Guidlines 2005.

36. Yulianti, O.N. Kajian Aktivitas Antioksidan dan Antimikroba Ekstrak Biji, Kulit Buah, Batang, dan Daun Tanaman Jarak Pagar (Jatropha curcas L.). Skripsi S1 Fakultas Teknologi Pertanian. Institut Pertanian Bogor:2009

37. Yusuf, Mentari Syahirah. 2014. Efektivitas Penggunaan Jintan Hitam (Nigella Sativa) Dalam Proses Percepatan Penyembuhan Luka Setelah Pencabutan Gigi. Makassar: UNHAS.

38. Widoyono, 2011. Penyakit Tropis: Epidemiologi, Penularan, Pencegahan \& Pemberantasannya. Edisi Kedua. Jakarta: Erlangga. Ciracas: 193-199. 
Tabel 1. Analisis Pengaruh Perlakuan Terhadap e-coli Secara In Vitro

\begin{tabular}{lll}
\hline Sumber & Nilai F & Signifikansi \\
\hline Perlakuan & 19,71 & $0,000^{*}$ \\
Konsentrasi & 0,726 & 0,577 \\
Perlakuan*Konsentrasi & 1,783 & $0,038^{*}$
\end{tabular}

Keterangan: uji anova (signifikansi<0,05) : berpengaruh nyata 